\title{
TINDAK PIDANA KEKERASAN TERHADAP PEREMPUAN (Studi Etiologi Kriminal di Wilayah Hukum Polres Banyumas)*
}

\author{
Ruby Hadiarti J ohny \\ Fakultas Hukum Universitas J enderal Soedirman Purwokerto \\ E-mail: ruby_hadiarty@yahoo.co.id
}

\begin{abstract}
The violence against women is increasing in number. This article discusses the factors underlying the occurrence and other form of violence against women that occurred in the Police Banyumas region. Sociological juridical approach used in this research. Specification of research is descriptive. The data used are primary and secondary data. The dominant factors that cause criminal violence to women are dominated by economic factors about $70 \%$ cultural factors about $15 \%$ affair factors about $10 \%$ and lack of communication between family factors about $5 \%$ The types of criminal violence to women based on data from LSM Lentera Perempuan WCC Banyumas, Victims, and Poice Banyumas region most of the type criminal violence to women is domestic violence, as physic, psychological, sexual violence, and negligence of household. The problem solving is with the litigation process or non litigation process. The litigation process with criminal law process and the non litigation process with mediation.
\end{abstract}

Keywords: Domestic violence, form of violence, cause of violence.

\begin{abstract}
Abstrak
Tindak pidana kekerasan terhadap perempuan semakin meningkat jumlahnya. Artikel ini membahas mengenai faktor-faktor yang melatarbelakangi terjadinya kekerasan terhadap perempuam dan bentukbentuk kekerasan terhadap perempuan yang terjadi di wilayah hukum Polres Banyumas. Metode penelitian yang digunakan dalam penelitian ini adalah metode pendekatan yuridis sosiologis dengan spesifikasi penelitian deskriptif. Data yang digunakan adalah data primer dan data sekunder. Faktor yang dominan dalam terjadinya kekerasan terhadap perempuan adalah faktor ekonomi sebesar $70 \% 15$ \% faktor budaya, 10\% fakor perselingkuhan, dan $5 \%$ faktor kurangnya komunikasi. Bentuk kekerasan terhadap perempuan baik berdasarkan data dari LSM Lentera Perempuan WCC Banyumas, korban, maupun Kepolisian Polres Banyumas, berada dalam lingkup tindak pidana Kekerasan Dalam Rumah Tangga (KDRT), berupa kekerasan fisik, kekerasan psikis, kekerasan seksual, dan penelantaran rumah tangga. Penyelesaian kasus-kasus kekerasan dalam rumah tangga dilakukan dengan proses litigasi atau non litigasi. Proses litigasi sesuai dengan hukum pidana, proses non litigasi dengan mediasi.
\end{abstract}

Kata kunci: Kekerasan dalam rumah tangga, bentuk kekerasan, sebab kekerasan.

\section{Pendahuluan}

Dewasa ini isu hak asasi manusia (HAM) sudah menjadi agenda yang makin penting, terutama paska berakhirnya Perang Dingin. Negara Barat semakin bersemangat mempromosikan advokasi HAM ke seluruh dunia, bahkan menjadikannya sebagai indikator dan faktor penentu dalam menentukan kebijakan dan hubungan luar negeri mereka. Pada saat ini dalam pene-

\footnotetext{
* Artikel ini merupakan artikel hasil penelitian dengan sumber dana dari FH UNSOED 2010
}

gakan HAM masih terjadi ketegangan dalam memahami dan mengimplementasikan HAM itu, antara negara-negara Barat dan negara-negara sedang berkembang, termasuk negara-negara Islam. ${ }^{1}$

Dikatakan oleh Abdul Wahid dan Muhammad Irfan bahwa potret Hak Asasi Manusia (HAM) adalah mosaik sejarah tentang penegak-

Abdul Wahid \& Muhammad Irfan, 2009, Perlindungan Terhadap Korban Kekerasan Seksual (Advokasi Atas Hak Asasi Perempuan), Bandung: Refika Aditama, hlm. vii. 
an kemerdekaan, kebebasan, keadilan, persamaan, perdamaian, persaudaraan, dan perlindungan. Mosaik yang mengalami pasang surut dalam cerminan kecermelangan dan keburaman jutaan wajah umat manusia. Hampir menjadi kenyataan, bahwa penindasan (Pelanggaran) terhadap HAM menempati fragmentasi historis dengan fenomena yang berulangkali, bahwa rekaman sejarah terhadap nasib hak-hak asasi juga senantiasa menyuarakan bagian-bagaian pembelaannya yang heroik atas musnahnya kemerdekaan itu sendiri, sehingga problema HAM telah berkembang sedemikian krusial, sehingga menjadi dilemma global. ${ }^{2}$

Problema HAM juga terjadi di Indonesia, salah satu jenis problema HAM adalah kekerasan terhadap perempuan. Kekerasan terhadap perempuan terjadi dilatar belakangi oleh berbagai faktor dan dalam berbagai bentuk seperti kekerasan terhadap fisik dan psikis.

Akhir-akhir ini di Indonesia marak sekali kasus kekerasan pada perempuan. Melalui media baik media cetak ataupun elektronik dapat diketahui bahwa kekerasan terhadap perempuan terjadi diberbagai kalangan baik kalangan selebirtis atau masyarakat pada umumnya. Salah satu contoh kasus kekerasan terhadap perempuan yang terjadi di kalangan selebritis adalah kekerasan yang terjadi terhadap bintang sinetron Novia Ardhana yang dilakukan oleh mantan suaminya yaitu Muhammad Bintang, ataupun kekerasan yang dilakukan Pasha "Ungu" terhadap istrinya Okky Agustina yang pada akhirnya beruj ung pada perceraian dan kembali terulang setelah mereka resmi bercerai.

Perkawinan merupakan peristiwa hukum yang akibatnya diatur oleh hukum, atau peristiwa hukum yang diberi akibat hukum. Jadi apabila terjadi ada tindakan kekerasan pasti ada akibat hukumnya. ${ }^{3}$ Terjadinya kekerasan

\footnotetext{
Ibid.

Trusto Subekti, "Sahnya Perkawinan Menurut UU No. 1/ 1974. Tentang Perkawinan Ditinjau dari Hukum Perjanjian", J urnal Dinamika Hukum FH Unsoed, Vol. 10 No. 3 September 2010. Lihat dan bandingkan dengan Wiratni Ahmadi, "Hak dan Kewajiban Wanita dalam Keluarga Menurut UU No. 1 Tahun 1974 tentang Perkawinan", J urnal Hukum Pro J usititia, Vol. 26 No. 4 Oktober 2008, hlm. 371-390
}

terhadap perempuan seperti contoh kasus tersebut tidak terlepas dari dianutnya budaya patrilinial oleh masyarakat Indonesia yang menempatkan perempuan sebagai manusia nomor dua sedangkan laki-laki adalah manusia nomor satu. Budaya ini terkonstruksi secara terus-menerus dalam waktu yang lama, sehingga melahirkan pola hubungan yang tidak seimbang antara perempuan dan laki-laki.

Ketidak perimbangan ini melahirkan dampak negatif dalam kehidupan masyarakat yang bermanivestasi dalam bentuk ketidakadilan terhadap perempuan seperti marginalisasi/peminggiran dalam mengakses kesempatan dari hasil kerja ekonomis subordinasi/penomerduaan dalam mengambil keputusan streriotipe/ pelabelan negatif, violence/ kekerasan serta double burden (beban berlebihan). Ketidakadilan terhadap perempuan menyebabkan lemahnya posisi perempuan yang menyebabkan perempuan rentan terhadap kekerasan.

Berdasarkan penelitian lembaga Legal Resource Center, keadilan gender dan hak azasi manusia diperoleh hasil bahwa jumlah kekerasan terhadap perempuan semakin tahun semakin besar jumlahnya. Korban kekerasan ini tidak hanya terbatas pada perempuan dewasa tetapi juga terjadi atas diri anak-anak. ${ }^{4}$

Kaitannya dengan HAM nampak dari berbagai pernyataan antara lain bahwa kekerasan terhadap perempuan merupakan rintangan terhadap pembangunan. Sebab kekerasan ini dapat menimbulkan akibat kumulatif yang tidak sederhana, seperti mengurangi kepercayaan diri perempuan, menghambat kemampuan perempuan untuk berpartisipasi penuh dalam kegiatan sosial, mengganggu kesehatan, mengurangi otonomi perempuan baik dalam bidang ekonomi, politik dan budaya. ${ }^{5}$

Kasus-kasus kekerasan khususnya terhadap perempuan tidak banyak yang dilaporkan dan diproses secara hukum karena banyak faktor, salah satu faktor yaitu dari hukum pidana

\footnotetext{
4 Dwi Habsari Retnaningrum, "Incest Sebagai Bentuk Manifestasi Kekerasan Terhadap Perempuan", Jurnal Dinamika Hukum, Fakultas Hukum UNSOED, Purwokerto, Vol. 9, 2009, hlm. 24.

5 lbid., hlm. 29
} 
sendiri. Proses peradilan pidana yang panjang itu ternyata hanya menitikberatkan pada pelaku kejahatan saja, sedangkan korban berada dalam posisi yang tidak menguntungkan. ${ }^{6}$

J umlah kasus kekerasan terhadap perempuan bagaikan fenomena gunung es, hal ini dikarenakan untuk mengetahui jumlah kekerasan terhadap perempuan hanya berdasarkan data laporan masyarakat, sedangkan kemungkinan lebih banyak lagi kasus yang tidak dilaporkan karena alasan ada hubungan khusus dengan korban dan perasaan malu dari korban apabila kasusnya diketahui orang.

Ada banyak cara dan tempat untuk mendapatkan keadilan, peradilan pidana hanya salah satu cara dan tempat yang dapat ditempuh. ${ }^{7}$ Demikianlah gambaran sekilas yang melatar belakangi terjadi kekerasan terhadap perempuan di masyarakat dan ketika perempuan mempertanyakan nasibnya seringkali dianggap sebagai sesuatu yang menyalahi kodratnya.

\section{Permasalahan}

Berdasarkan latar belakang di atas, ada dua permasalahan yang dibahas pada artikel ini. Pertama, berkaitan dengan bentuk-bentuk kekerasan terhadap perempuan yang terjadi di wilayah hukum Polres Banyumas; dan kedua, mengenai faktor-faktor yang melatarbelakangi terjadinya kekerasan terhadap perempuam di wilayah hukum Polres Banyumas.

\section{Metode Penelitian}

Metode pendekatan yang digunakan adalah yuridis sosiologis. Dalam pendekatan ini hukum akan diartikan sebagai perilaku sosial yang dalam interaksinya tidak lepas dari pengaruhpengaruh di luar bidang hukum atau meneliti bekerjanya hukum dalam masyarakat. Penelitian hukum sosiologis ini dimaksudkan sebagai usaha mendekati masalah yang diteliti dengan sifat hukum yang nyata atau sesuai dengan

\footnotetext{
6 Agus Raharjo, Sunaryo dan Nurul Hidayat, "Pendayagunaan Teknologi, Informasi dalam Pemberdayaan Masyarakat untuk Mengawasi Bekerjanya Sistem Peradilan Pldana di J awa Tengah", J urnal Dinamika Hukum, Vol. 10 No. 3 September 2010, Fakultas Hukum Unsoed, Purwokerto.

7 lbid.
}

kenyataan yang hidup dalam masyarakat.

Pada penelitian sosiologis, maka yang akan diteliti pada awalnya adalah data sekunder adalah sumber data yang terdiri dari bahan hukum primer yang berupa peraturan perundang- undangan, dokumen resmi, buku-buku literatur, artikel ilmiah, hasil penelitian para ahli yang berkaitan dengan materi yang diteliti, kemudian dilanjutkan dengan penelitian terhadap data primer adalah data pertama yang diperoleh secara langsung dari para responden yaitu perempuan yang mengalami kekerasan, kepolisian Polres Banyumas, dan pengurus LSM Lentera Perempuan Women Crisis Center Banyumas. Spesifikasi penelitian yang digunakan dalam penelitian ini adalah deskriptif, yaitu menggambarkan bentuk-bentuk kekerasan terhadap perempuan di wilayah hukum Polres Banyumas dan faktor-faktor yang melatarbelakangi terjadinya kekerasan terhadap perempuan.

\section{Pembahasan \\ Kondisi Riil Kekerasan Terhadap Perempuan Di Banyumas Berdasarkan Perolehan Data Primer}

LSM Lentera Perempuan Women Crisis Center Banyumas adalah sebuah lembaga swadaya masyarakat yang menangani kasus perempuan korban kekerasan guna memperjuangkan hak dan keadilan kaum perempuan di Indonesia khususnya di Kabupaten Banyumas. Berdasarkan penjelasan yang diberikan oleh Ibu Eri Singgih Astuti, S.H selaku Koordinator Divisi Advokasi dan Pendampingan yang bertugas untuk membantu manangani kasus kekerasan terhadap perempuan diperoleh data sebagai berikut. $^{8}$

Pertama, ada banyak kasus kekerasan terhadap perempuan yang dilaporkan ke LSM ini, dalam kurun waktu 2004-2009 kurang lebih ada 400 kasus. Di antara sekian banyak kasus itu, faktor yang melatarbelakangi kekerasan terhadap perempuan adalah sebagai berikut:

\footnotetext{
8 Wawancara dilakukan pada Rabu, 14 Juli 2010. Lihat dan bandingkan dengan tulisan C. Djisman Samosir, "Faktor-Faktor Yang Mengakibatkan Tidak Terungkapnya Suatu Kejahatan", J urnal Hukum Pro J usititia, Vol. 24 No. 3 J uli 2006, hlm. 246-270.
} 
(a) faktor ekonomi (biasanya faktor ini melatar belakangi terjadinya kekerasan dalam lingkup rumah tangga); (b) faktor budaya (masyarakat Indonesia menganut budaya Patrilineal yang menempatkan perempuan sebagai makhluk yang harus tunduk kepada lelaki); (c) perselingkuhan (faktor ini juga melatar belakangi terjadinya kekerasan terhadap perempuan dalam lingkup rumah tangga hal ini dikarenakan pasangan memiliki pasangan selingkuh); (d) kurangnya komunikasi antar keluarga (faktor ini paling sering melatar belakangi kekerasan terhadap anak perempuan, hal ini dikarenakan hubungan antara anak dengan orang tua tidak berjalan harmonis). Prosentase masing-masing-masing faktor tersebut adalah kurang lebih $70 \%$ kekerasan terhadap perempuan dialatarbelakangi oleh faktor ekonomi, 15\% faktor budaya, 10\% faktor perselingkuhan, dan 5\% faktor kurangnya komunikasi.

Kedua, bentuk kekerasan terhadap perempuan yang dilaporkan ke LSM Lentera Perempuan WCC Banyumas berupa Kekerasan Dalam Rumah Tangga (KDRT), Kekerasan Terhadap Anak (KTA), kekerasan seksual misalnya pemerkosaan dan pencabulan, Kekerasan Dalam Pacaran (KDP), Anak Bermasalah Dengan Hukum (ABH), Buruh Migran. Komposisi prosentase masing-masing bentuk kekerasan itu adalah KDRT sekitar 40\% Seksual 30\% KTA $14 \%$ Buruh Migran 8\% KDP 7\%, ABH 1\%

Ketiga, langkah yang dilakukan oleh LSM Lentera Perempuan WCC Banyumas atas adanya laporan kekerasan adalah sesuai dengan Standart Operasional Prosedur (SOP). Langkah pertama yang diambil untuk menangani kasus kekerasan terhadap perempuan adalah melakukan penggalian dan pengembangan informasi (laporan yang masuk) kepada pihak-pihak terkait, apabila laporan tersebut bukanlah kasus maka dilakukan pembekalan sumber daya manusia, akan tetapi apabila laporan tersebut benar merupakan kasus maka diberikan bantuan yang berupa pelayanan advokasi, pendampingan di proses hukum misalnya pada tahap penyidikan, atau pendampingan melalui proses non litigasi misalnya pendampingan medis dan psikologis, bantuan- bantuan tersebut bertujuan untuk pemulihan pemberdayaan korban.

Berdasarkan pada data tersebut maka dapat diketahui bahwa kekerasan terhadap perempuan yang dilaporkan kepada LSM Lentera Perempuan WCC Banyumas semuanya telah diatur dalam peraturan perundang-undangan yang berlaku, misalkan dalam hal kekerasan terhadap perempuan dalam bentuk Kekerasan Dalam Rumah Tanggga (KDRT), diatur dalam Undang- Undang Nomor 23 Tahun 2004 Tentang Penghapusan Kekerasan Dalam rumah tangga dan Deklarasi Beijing. Apabila dikaitkan dengan hasil wawancara maka dapat diketahui bahwa KDRT yang terjadi paling banyak kekerasan fisik yang diatur pada Pasal 6 UU No 23 Tahun 2004, psikis diatur dalam Pasal 7 UU No.23 Tahun 2004, penelantaran rumah tangga diatur dalam Pasal 9 UU NO.23 Tahun 2004, dan kekerasan seksual diatur dalam pasal 8 UU No.23 Tahun 2004.

Apabila KDRT yang dilaporkan kepada LSM Lentera Perempuan WCC Banyumas dikaitkan dengan Deklarasi Beijing Tahun 1995, maka kerusakan yang ditimbulkan berupa penderitaan fisik, psikologis. Hal ini diatur dalam Pasal 113 yaitu:

Kekerasan terhadap perempuan berarti segala bentuk kekerasan gender yang akibatnya berupa atau dapat berupa kerusakan atau penderitaan fisik, seksual, psikologis pada perempuan-perempuan termasuk disini ancaman-ancaman dari perbuatan- perbuatan semacam itu, seperti paksaan atau perampasan semena - mena atas kemerdekaan, baik yang terjadi di tempat umum atau dalam kehidupan pribadi seseorang.

Kekerasan seksual diatur dalam KUHP Bab XIV tentang Kejahatan terhadap kesusilaan dalam Pasal 284 mengenai perzinahan, dan Pasal 285 meneganai pemerkosaan. Kekerasan Terhadap anak, misalnya kekerasan seksual yaitu pencabulan diatur Pasal 290 dan Pasal 292 KUHP, sedangkan Untuk kasus kekerasan dalam pacaran diatur dalam Bab XX tentang penganiayaan dalam Pasal 351 dan Pasal 352 KUHP. Kekerasan terhadap buruh migran sampai saat 
ini Indonesia belum memiliki undang-undang yang khusus mengatur hal tersebut, tetapi dapat diproses hukum berdasarkan KUHP.

LSM Lentera Perempuan WCC Banyumas dalam menangani permasalahan tersebut menggunakan proses non litigasi dan litigasi. Proses non litigasi melalui mediasi anatar para pihak yang terlibat, hal ini dilakukan untuk memperoleh perdamaian dan menjamin hak-hak korban. Proses litigasi melalui proses hukum pada umumnya dimulai dengan tahap penyelidikan hingga proses persidangan. Akan tetapi sebagaian besar kasus kekerasan terhadap perempuan ditangani melalui proses non litigasi dengan mediasi.

Berdasarkan data yang diperoleh dari 4 (empat) perempuan yang mengalami kasus kekerasan atau yang menjadi korban, dan dari hasil wawancara dengan beberapa responden, dapat dijelaskan bahwa faktor-faktor penyebab terjadinya kekerasan karena kesulitan ekonomi para suami responden yang tidak mampu memenuhi kebutuhan hidup maksimal, ini pun karena faktor pendidikan dan pekerjaan. Pelaku mempunyai hubungan dekat (suami) dengan responden dan para responden tidak melakukan upaya apapun atas perbuatan kekerasan yang dilakukan dengan alasan malu apabila aibnya diketahui orang dan masih mencintai pelaku (suami).

Data yang diperoleh dari Polres Banyumas, yang dikemukakan oleh Iptu Icuk Sukiya, S.H., menunjukkan beberapa hal. Pertama, bahwa terdapat banyak kasus kekerasan terhadap perempuan yang dilaporkan antara tahun 2004-2009 kurang lebih 150 kasus dan faktorfaktor yang melatar belakangi adalah faktor ekonomi yang paling dominan, temasuk suami yang tidak memiliki pekerjaan tetap, sehingga tidak mampu memberi nafkah maksimal. Selain itu faktor peselingkuhan yang menyebabkan kecemburuan dan berakhir dengan pertengkaran yang diikuti dnegan pemukulan dan sebagainya.

Kedua, faktor yang paling dominan yang melatarbelakangi terjadinya kekerasan terhadap perempuan, Kurang lebih $70 \%$ KDRT dila- tarbelakangi oleh faktor ekonomi, 30\% faktor perselingkuhan. Ketiga, ada beberapa bentuk atau jenis-jenis KDRT yang ditangani oleh Polres Banyumas, yaitu: (a) kekerasan fisik, yaitu perbuatan yang mengakibatkan rasa sakit, jatuh sakit, atau luka berat, seperti pemukulan, penendangan; (b) kekerasan psikis, yaitu perbuatan yang mengakibatkan ketakutan, hilangnya rasa percaya diri, hilangnya kemampuan untuk bertindak, rasa tidak berdaya, merasa terhina atau dilecehkan; (c) kekerasan seksual, seperti pemaksaan melakukan hubungan intim, atau dipaksa melakukan hubungan intim guna kepentingan komersial; dan (d) Penelantaran rumah tangga, pihak suami pergi dalam waktu yang lama tanpa pemberitahuan dan tidak bertanggung jawab terhadap kelangsungan rumah tangga. Prosentase bentuk kekerasan tersebut adalah kekerasan fisik sekitar $55 \%$ penelantaran rumah tangga $20 \%$ kekerasan psikis $15 \%$ kekerasan seksual $10 \%$

Keempat, cara penyelesaian KDRT yang di lakukan oleh Polres Banyumas disesuaikan dengan tujuan Undang-undang Penghapusan Kekerasan Dalam Rumah Tangga Nomor 23 Tahun 2004 yaitu mengharmonisasikan kehidupan berumah tangga, maka apabila terjadi kekerasan dalam lingkup rumah tangga langkah awal adalah melakukan proses mediasi antara pelaku, korban, dan polisi sebagai mediator. Apabila dalam tahap mediasi telah tercapai kesepakatan perdamaian maka proses hukum dihentikan, akan tetapi apabila dalam tahap mediasi tidak ditemukan kesepakatan maka kasus akan diproses lebih lanjut melalui proses hukum. Sebagian besar peneyelesaian kasus Kekerasan Terhadap Rumah Tangga (KDRT) melalui mediasi.

Hukum mempunyai tujuan dan sasaran yang hendak dicapai. Tujuan pokok hukum adalah menciptakan tatanan dalam masyarakat yang tertib, menciptakan ketertiban dan keseimbangan. ${ }^{9}$ Apabila berdasarkan Kitab UndangUndang Hukum Pidana (KUHP) kekerasan terhadap perempuan pengaturannya tersebar dalam

Hibnu Nugroho, "Perlindungan Hukum Bagi Korban "Bank Gelap", J urnal Dinamika Hukum Fakultas Hukum Unsoed, Purwokerto, Vol. 9 2009,, hlm. 19. 
beberapa Bab dan pasal. Kekerasan terhadap perempuan berupa kesusilaan daiatur dalam Bab XIV tentang Kejahatan terhadap kesusilaan Pasal 284 tentang perzinahan dan Pasal 285 mengenai perkosaan, Bab IX tentang kejahatan terhadap nyawa diatur dalam Pasal 338 tentang pembunuhan dan Pasal 340 tentang pembunuhan berencana. Penganiayaan diatur dalam Bab XX Pasal 351, Pasal 352, Pasal 353, Pasal 354, Pasal 355, Pasal 356 jo. Undang- undang Nomor 23 Tahun 2004 Tentang Penghapusan Kekerasan Dalam Rumah Tangga. Kekerasan yang menyebabkan mati atau luka-luka karena kealpaannya diatur Bab XXI dalam Pasal 359, Pasal 360, Pasal 361.

Penulis juga melihat bahwa perempuan yang mengalami kekerasan tidak berani melaporkan kekerasan tersebut ke pihak yang berwajib atau ke proses hukum. Hal ini dikarenakan korban biasanya memiliki hubungan yang dekat dengan pelaku, apabila korbannya adalah istri, maka alasannya istri masih mencintai suaminya (pelaku) atau karena alasan malu aibnya diketahui banyak orang apabila kekerasan tersebut dilaporkan. Penyelesaian perkara pidana melalui jalur non litigation, merupakan jalur alternative di samping jalur utama yaitu litigasi. ${ }^{10}$

Bagi para perempuan yang menjadi korban tindak pidana kekerasan baik yang dilakukan di dalam rumah maupun di luar rumah membuat trauma dalam kehidupannya. Secara psikologis perempuan korban trafficking biasanya akan memiliki trauma yang dalam, karena rentetan peristiwa yang mereka alami. ${ }^{11}$

10 Agus Raharjo, "Mediasi sebagai Basis dalam Penyelesaian Perkara Pidana", J urnal Mimbar Hukum, Fakultas Hukum UGM, Yogyakarta, Volume 20, 2008, hlm. 93.

11 Siti Muflichah dan Rahadi Wasi Bintoro, "Traffiking: Suatu Studi Tentang Perdagangan Perempuan dari Aspek Sosial, Budaya dan Ekonomi di Wilayah Kab. Banyumas", Jurnal Dinamika Hukum, Fakultas Hukum Unsoed, Purwokerto, 2009, hlm. 164. Lihat dan bandingkan dengan tulisan Fahmi, "Penegakan Hukum Tindak Pidana Trafficking in Person di Kabupaten Karimun, Kepulauan Riau", J urnal Hukum Respublica, Vol. 7 No. 1 Tahun 2007, hlm. 17-26; dan Maidin Gulton dan Taufik Siregar, "Penegakan Hukum Atas Tindak Pidana Perdagangan (Trafficking) Anak", J urnal Hukum Pro J usitita, Tahun XXIII No. 2 April 2005, hlm. 3-13.

\section{Peraturan-Peraturan yang Berkaitan dengan Kekerasan Terhadap Perempuan}

Peraturan-peraturan yang berkaitan dengan kekerasan terhadap perempuan terdapat pada KUHP, UU No. 23 Tahun 2004, dan Deklarasi Beijing Tahun 1995. Beberapa pasal dalam KUHP yang dapat digunakan atau dikategorikan berkaitan dengan kekerasan terhadap perempuan adalah: (a) Bab XIV tentang Kejahatan terhadap kesusilaan diatur dalam Pasal 284, Pasal 285, Pasal 286, Pasal 287, Pasal 288, Pasal 290, 292. Dari pasal- pasal tersebut yang paling sering digunakan untuk mendakwa pelaku kekerasan terhadap perempuan adalah Pasal 284 dan Pasal 285; (b) Bab IX tentang kejahatan terhadap nyawa diatur dalam Pasal 338, Pasal 339, dan Pasal 340; (c) Bab XX tentang penganiayaan yang diatur dalam Pasal 351, Pasal 352, Pasal 353, Pasal 354, Pasal 355, Pasal 356; dan (d) Bab XXI tentang menyebabkan mati atau luka- luka karena kealpaannya diatur dalam Pasal 359, Pasal 360, Pasal 361. Sebagian besar kasus- kasus yang masuk ke kepolisian biasanya dituntut dengan pasal-pasal tersebut di atas.

Kekerasan dalam rumah tangga menurut Undang Undang Nomor 23 Tahun 2004 (Pasal 1 angka 1) adalah setiap perbuatan terhadap seseorang terutama perempuan, yang berakibat timbulnya kesengsaraan atau penderitaan secara fisik, seksual, psikologis, dan/ atau penelantaran rumah tangga termasuk ancaman untuk melakukan perbuatan, pemaksaan, atau perampasan kemerdekaan secara melawan hukum dalam lingkup rumah tangga. ${ }^{12}$

Bentuk atau jenis kekerasan yang dilarang dilakukan dalam lingkup rumah tangga diatur dalam Pasal 5 Undang- Undang Nomor 23 Tahun 2004, yang meliputi kekerasan fisik; kekerasan psikis; kekerasan seksual; atau penelantaran rumah tangga. Pengertian dari bentukbentuk atau jenis-jenis kekerasan yang dilarang

12 Lihat uraian dan analisis mengenai KDRT dalam A. Reni Widyaastuti, "Hukum dan Kekerasan dalam Rumah Tangga", J urnal Hukum Pro Jusitita, Vol. 25 No. 3 J uli 2007, hlm. 257-269; Rena Yulia, Implementasi UU No. 23 Tahun 2004 tentang Penghapusan KDRT dalam Proses Penegakan", Jurnal Hukum Pro Jusitita, Vol. 24 No. 3 J uli 2006, hlm. 292-300. 
dalam lingkup rumah tangga diatur dalam Pasal 6 sampai dengan Pasal 9.

Pasal 6

Kekerasan fisik sebagaimana yang dimaksud dalam Pasal 5 huruf a adalah perbuatan yang mengakibatkan rasa sakit, jatuh sakit, atau luka berat.

\section{Pasal 7}

Kekerasan psikis sebagaimana dimaksud dalam Pasal 5 huruf $b$ adalah perbuatan yang mengakibatkan ketakutan, hilangnya rasa percaya diri, hilangnya kemampuan untuk bertindak, rasa tidak berdaya, dan/ atau penderitaan psikis berat pada seseorang.

\section{Pasal 8}

Kekerasan seksual sebagaimana dimaksud dalam Pasal 5 huruf $c$ meliputi:

a. pemaksaan hubungan seksual yang dilakukan terhadap orang yang menetap dalam lingkup rumah tangga tersebut; atau

b. pemaksaan hubungan seksual terhadap salah seorang dalam lingkup rumah tangganya dengan orang lain untuk tujuan komersial dan/atau tujuan tertentu.

Pasal 9

(1) Setiap orang dilarang menelantarkan orang dalam lingkup rumah tangganya, padahal menurut hukum yang berlaku baginya atau karena persetujuan atau perjanjian ia wajib memberikan kehidupan, perawatan, atau pemeliharaan kepada orang tersebut.

(2) Penelantaraan sebagaimana dimaksud pada ayat (1) juga berlaku bagi setiap orang yang mengakibatkan ketergantungan ekonomi dengan cara membatasi dan/ atau melarang untuk bekerja yang layak di dalam atau di luar rumah sehingga korban berada di bawah kendali orang tersebut.

Ancaman sanksi pidana terhadap masingmasing bentuk KDRT berbeda, untuk kekerasan fisik daitur dalam Pasal 44 UU No 23 Tahun

2004, yaitu:

Pasal 44

(1) Setiap orang yang melakukan perbuatan kekerasan fisik dalam lingkup rumah tangga sebagaimana dimaksud dalam Pasal 5 huruf a dipidana dengan pidana penjara paling lama 5 (lima) tahun atau denda paling banyak Rp 15.000.000,00 (lima belas juta rupiah).

(2) Dalam hal perbuatan sebagaimana dimaksud pada ayat (1) mengakibatkan korban mendapat jatuh sakit atau luka berat, dipidana dengan pidana penjara paling lama 10 (sepuluh) tahun atau denda paling banyak Rp 30. $000.000,00$ (tiga puluh juta rupiah).

(3) Dalam hal perbuatan sebagaimana dimaksud pada ayat (2) mengakibatkan matinya korban, dipidana dengan pidana penjara paling lama 15 (lima belas) tahun atau denda paling banyak Rp 45.000.000,00 (empat puluh lima juta rupiah).

(4) Dalam hal perbuatan sebagaimana dimaksud pada ayat (1) dilakukan oleh suami terhadap isteri atau sebaliknya yang tidak menimbulkan penyakit atau halangan untuk menjalankan pekerjaan jabatan atau mata pencaharian atau kegiatan sehari-hari, dipidana dengan pidana penjara paling lama 4 (empat) bulan atau denda paling banyak Rp 5.000.000,00 (lima juta rupiah).

Anacaman pidana terhadap kekerasan psikis daitur dalam Pasal 45 UU No. 23 Tahun 2004, yaitu:

Pasal 45

(1) Setiap orang yang melakukan perbuatan kekerasan psikis dalam lingkup rumah tangga sebagaimana dimaksud dalam Pasal 5 huruf $b$ dipidana dengan pidana penjara paling lama 3 (tiga) tahun atau denda paling banyak Rp 9.000.000,00 (sembilan juta rupiah).

(2) Dalam hal perbuatan sebagaimana dimaksud pada ayat (1) dilakukan oleh suami terhadap istri atau sebaliknya yang tidak menimbulkan penyakit atau halangan untuk menjalankan pekerjaan jabatan atau mata pencaharian atau kegiatan sehari-hari, dipidana dengan pidana penjara paling lama 4 (empat) bulan atau denda paling banyak Rp 3.000.000,00 (tiga juta rupiah). 
Ancaman hukuman terhadap kekerasan seksual diatur dalam Pasal 46 dan Pasal 47 UU No. 23 Tahun 2004. Pasal 46 mengatur untuk kekerasan seksual yang dimaksud dalam Pasal 8 huruf a dengan ancaman pidana penjara paling lama 12 (dua belas) tahun atau denda paling banyak Rp. 36.000.000,00 (tiga puluh enam juta rupiah, sedangkan Pasal 47 mengatur ancaman pidana untuk kekerasan seksual yang dimaksud dalam Pasal 8 huruf b dengan ancaman maksimal penjara 15 (lima belas) tahun atau denda paling sedikit Rp.12.000.000, 00 (dua belas juta rupiah) atau denda paling banyak Rp.300.000. 000,00 (tiga ratus juta rupiah). Dalam hal KDRT berupa penelantaran rumah tangga ancaman pidana diatur dalam Pasal 49 UU No. 23 Tahun 2004, yaitu:

\section{Pasal 49}

Dipidana dengan pidana penjara paling lama 3 (tiga) tahun atau denda paling banyak Rp 15.000.000,00 (lima belas juta rupiah), setiap orang yang:

a. menelantarkan orang lain dalam lingkup rumah tangganya sebagaimana dimaksud dalam Pasal 9 ayat (1);

b. menelantarkan orang lain sebagaimana dimaksud dalam Pasal 9 ayat (2).

\section{Pengertian Kejahatan Kekerasan Menurut Kri- minologi}

Dikatakan oleh Herman Mannheim bahwa kejahatan adalah

"By tradition.... are required first to define their subject, but if they follow this tradition, they are citizied ignoring the fact that meaningful definition can not be produced without the knowledge wich the textbook expected to supply".

Berdasarkan pendapat Herman Mannheim tersebut, jelas bahwa pemberian suatu batasan sangat memerlukan berbagai pengetahuan yang berbobot yang dapat menunjang pokok masalah yang akan dibahas. Namun walaupun demikian, hal itu tidaklah berarti bahwa kita tidak boleh memberikan batasan (walau sifatnya sementara). Oleh karena sesuatu batasan dianggap dapat dijadikan landasan/tolak pangkal bagi pembahasan-pembahasan selanjutnya. Herman
Mannheim berpendapat pula bahwa "Crime is first of all, a legal conception, human behavior punishable under the criminal law" akan tetapi selajutnya dikatakan bahwa "It is, however, much more than only a legal phenomenon". ${ }^{13}$

Berbagai pendapat telah diketengahkan tentang batasan kejahatan, pendapat-pendapat mana ada yang luas dan ada yang sempit. Perbedaan luas-sempitnya batasan yang diberikan tergantung dari sudut mana kejahatan tersebut dipandang. Lazimnya ada sementara anggapan di kalangan para ahli bahwa pandangan kejahatan dari segi yuridis menghendaki batasan dalam arti sempit yakni: kejahatan sebagaimana telah diatur dalam undang-undang. Pandangan kejahatan dalam arti luas menghendaki tidak hanya batasan dalam pengertian undangundang, melainkan juga meliputi pengertian kej ahatan dalam arti sosiologis atau psikologis.

Kejahatan dan penjahat bisa dipelajari, tentunya apabila melihat rumah penjara di ruang terjadi prisonisasi. Pengalaman dengan penjahat dimaksudkan pula bahwa terdapat proses saling belajar antara napi dalam dunia kejahatan, dapat dijelaskan dengan teori dari Edwin Sutherland tentang Differentual Association. Teori ini berdasarkan pada proses belajar yaitu bahwa perilaku kejahatan adalah perilaku yang dipelajari. ${ }^{14}$

Sudarto berpendapat bahwa perbuatan yang dapat dipidana atau disingkat perbuatan jahat itu merupakan objek ilmu pengetahuan hukum pidana (dalam arti luas) dan harus dibedakan, yaitu perbuatan jahat sebagai gejala masyarakat di pandang secara konkrit sebagaimana terwujud dalam masyarakat (sociaal verschijnsel, erscheinung, poena), ialah perbuatan manusia yang memeperkosa/ menyalahi normanorma dasar dari masyarakat dalam konkreto ini adalah pengertian "perbuatan jahat" dalam arti krimonologis (criminologisch misdaadsbegrip); dan perbuatan jahat dalam arti hukum

13 Romli Atmasasmita, 1983, Capita Selecta Kriminologi, Bandung: Armico, hlm. 12.

14 Angkasa, Over Capacity Narapidana Pemasyarakatan di Lembaga Pemasyarakatan, Faktor Penyebab, Implikasi Negatif, serta Solusi dalam Upaya Optimalisasi Pembinaan Narapidana, Jurnal Dinamika Hukum, Fakultas Hukum Unsoed, Purwokerto, 2010, hlm. 216. 
pidana (strafrechtelijk misdaadsbegrip), ialah sebagaimana terwujud dalam in abstracto dalam peraturan-peraturan pidana. ${ }^{15}$

Dari anggapan sementara dimaksud, tampak bahwa dikehendaki adanya perbedaan secara tegas dan nyata antara batasan kejahatan dalam arti undang- undang dan dalam arti sosiologis kriminologis ataupun psikologis. Anggapan sementara yang disebut terdahulu sesungguhnya tidaklah seluruhnya benar, oleh karena perkembangan IImu Hukum (Pidana) dan Kriminologi pada dewasa ini sudah sedemikian pesatnya, sehingga sangatlah sukar ditemukan suatau batasan tentang kejahatan yang tegas.

Dapat dikemukakan bahwa, baik kejahatan dalam arti undang-undang maupun dalam arti sosiologis adalah relatif adanya. Di lapangan kriminologi diketahui bahwa satu-satunya kriminolog yang menghendaki batasan kejahatan dalam arti tersendiri dan luas, adalah Thorsten Sellin. Selain telah berusaha mengetengahkan suatu pengertian atau istilah yang sama sekali lain baik dipandang dari sudut Hukum Pidana maupun Kriminologi, ia telah mengetengahkan pengertian istilah "conduct norms", dan baginya kriminologi adalah mempelajari conduct-norms dan ia mengemukakan sebagai berikut:

"These facts lead to the inescapable conclusion that study of conduct norms would afford a sounder basis for the development of scientific categories than a study of crime as defined in the criminal law. .... Such study involve the isolation and classification of norma into universal ca-tegories, transcending political, and ot-her boundaries, a necessity imposed by the logic of science". ${ }^{16}$

M.A.Elliot berpendapat bahwa kejahatan adalah suatu problem dalam masyarakat modern atau suatu tingkah laku yang gagal, yang melangar hukum dan dapat dijatuhi hukuman penjara, mati, denda, dan Iain-lain. ${ }^{17}$ Selain itu definisi kejahatan dapat dipandang secara so-

15 Sudarto, 1990, Hukum Pidana Jilid 1 A-B, Purwokerto: Fak. Hukum-UNSOED, hlm. 23.

16 Romly, op.cit, hlm. 14.

17 Hari Saherodji, 1980, Pokok-Pokok Kriminologi, Jakarta: Aksara Baru, hlm. 14. siologis memiliki dua unsur/ elemen, yaitu: (a) Kejahatan itu adalah yang merugikan secara ekonomis dan, (b) merugikan secara psychologis/dan melukai perasaan susila dari suatu kelompok manusia dimana orang-orang itu oleh karenanya berhak melahirkan celaan. Pengertian secara sosiologis ini lebih luas dari pada pengertian secara yuridis, sebab tidak hanya menekankan pada pelanggaran hukum, melainkan juga segi-segi di luar hukum, misalnya: suatu perbuatan yang tidak melanggar hukum tetapi sudah patut mendapat celaan dari masyarakat (buang air kecil disembarang tempat). ${ }^{18}$

Jadi, pengertian kejahatan secara sosiologi lebih luas daripada pengertian secara yuridis yang hanya menekankan pada pelanggaran hukum, pengertian yuridis ini lebih dikenal dengan istilah tindak pidana. Menurut penulis, tindak pidana kekerasan terhadap perempuan lebih banyak merupakan pelanggaran terhadap hukum pidana, misalnya: kekerasan yang menimbukan kematian, kekerasan yang menimbulkan luka berat, yang semuanya diatur dalam KUHP, namun apabila kita mencari faktor-faktor terjadinya kejahatan melihat dari segi etiologi kriminal.

Stephen Schafer dalam suatu studinya mengenai kejahatan-kejahatan kekerasan di Florida mendasarkan rumusannya pada batasan Kelompok Internasional Para Ahli PBB yang beranggapan bahwa kejahatan-kejahatan kekerasan yang utama adalah pembunuhan, penganiayaan berat, serta perampokan dan pencurian berat, sedangkan pelakunya adalah mereka yang melakukan kejahatan yang berakibat kematian maupun luka bagi sesama manusia. ${ }^{19}$ Mengenai pola-pola kekerasan, Martin R. Haskell dan Lewis Yablonsky mengemukakan adanya empat kategori yang mencakup hampir semua pola- pola kekerasan. ${ }^{20}$

Pertama, kekerasan legal yaitu kekerasan ini dapat berupa kekerasan yang didukung oleh hukum, misalnya: tentara yang melakukan tu-

$18 \quad$ Ibid, hlm. 15.

19 Mulyana W Kusuma, 1981 Analisa Kriminologi tentang Kejahatan-Kejahatan Kekerasan, Jakarta: Ghalia Indonesia, hlm. 24.

20 Ibid, hlm. 25-26 
gas dalam peperangan, maupun kekerasan yang dibenarkan secara legal, misalnya: sport- sport agresif tertentu serta tindakan-tindakan tertentu untuk mepertahankan diri. Kedua, kekerasan yang secara sosial memperoleh sanksi yaitu suatu faktor penting dalam menganalisis kekerasan adalah tingkat dukungan atau sanksi sosial terhadapnya. Misalnya: tindakan kekerasan seorang suami atas pezina akan memperoleh dukungan sosial.

Ketiga, kekerasan rasional, yaitu beberapa tindakan kekerasan yang tidak legal akan tetapi tak ada sanksi sosialnya adalah kejahatan yang dipandang rasional dalam konteks kejahatan. Misalnya: pembunuhan dalam kerangka suatu kejahatan terorganisasi, tentang jenis kejahatan ini dikatakan bahwa orang-orang yang terlibat dalam pekerjaannya pada kejahatan terorganisasi yaitu dalam kegiatan- kegiatan seperti perjudian, pelacuran, serta lalu-lintas narkotika secara tradisional menggunakan kekerasan untuk mencapai hasil lebih dari pada orang-orang yang ada di lingkungan tersebut. Keempat, kekerasan yang tidak berperasaan yaitu kekerasan ini disebut juga “irrational violence", yang terjadi tanpa adanya provokasi terlebih dahulu, tanpa memperlihatkan motivasi tertentu dan pada umumnya korban tidak dikenal oleh pelakunya. Dapat digolongkan ke dalamnya adalah apa yang dinamakan "raw violence" yang merupakan ekspresi langsung dari gangguan psikis seseorang dalam saat tertentu kehidupannya.

Selain itu Galtung mendefinisikan kekerasan dalam pengertian yang lebih luas sebagai "any avoidable impediment to self-realization" yang berarti segala sesuatu yang menyebabkan orang terhalang untuk mengaktualisasikan potensi dirinya secara wajar. ${ }^{21}$ Menurut Muladi masalah kekerasan terhadap perempuan saat ini tidak hanya merupakan masalah individual atau masalah nasional, tetapi sudah merupakan

\footnotetext{
21 Mohammad Azzam Manan, "Kekerasan dalam Rumah Tangga dalam Perspektif Sosiologis", Jurnal Legislasi Indonesia, Dirjen Kum Dan RI, Jakarta, Vol. 5, 2008, hlm. 13
}

masalah global. Dalam hal-hal tertentu bahkan dikatakan sebagai masalah transnasional. ${ }^{22}$

Ada beberapa tahap perkembangan dalam mempelajari kejahatan dalam kriminologi. Pertama, mempelajari kejahatan secara sederhana (belum secara ilmiah). Dalam periode/ masa ini diketahui dan dikenal pelbagai pendapat dari para cendikiawan terutama dari para Filosof mengenai kejahatan. Beberapa pendapat terkenal pada periode/masa ini adalah berasal dari Filosof Yunani, yakni Aristoteles (384-322 SM) yang dalam bukunya "Politiek", menyatakan kemiskinan menimbulkan kejahatan dan pemberontakan. Kejahatan besar tidak diperbuat untuk memperoleh apa yang perlu untuk hidup, tetapi untuk kemewahan. ${ }^{23}$ Selain Aristoteles, Plato (427-347 SM) dalam bukunya "Republiek" juga menyatakan, "emas, manusia adalah merupakan sumber dari banyak kejahatan". Jadi makin tinggi kekayaan dalam pandangan manusia, makin merosot penghargaan terhadap kesusilaan. Adalah jelas, bahwa dalam setiap negara di mana terdapat banyak orang miskin, dengan diam-diam terdapat bajingan-bajingan, tukang copet, pemerkosaan agama dan penjahat dari bermacam- macam corak. ${ }^{24}$

Kedua, mempelajari kejahatan secara ilmiah. Pendapat atau hasil penyelidikan baru dapat dikatakan merupakan suatu ilmu pengetahuan (science), apabila pendapat atau hasil penyelidikan dimaksud merupakan "a system of knowledge" yang mengenai sesuatu subyek atau beberapa subyek pembahasan.

Periode masa mempelajari kejahatan secara ilmiah diawali dengan lahirnya Kriminologi sebagai ilmu pengetahuan yang mempelajari dan menyelidiki kejahatan pada tahun 1836. Tokoh-tokoh yang terkenal mempelajari kejahatan secara sistematis, yaitu Cesare Lombroso (1835-1905). Lombroso dikenal dalam sejarah kriminologi sebagai penemu dan pendasar ajaran atau teori atavisme dan manusia penjahat (criminal man). Karya terkenal Lombroso yaitu

22 Ibid, hlm. 28.

23 Romli Atmasasmita, op.cit, hlm. 16

24 lbid. 
"L'uomo delinquent" dalam bukunya tersebut dikatakan bahwa, penjahat memiliki perbedaan ciri-ciri physic yang sangat menonjol dibandingkan dengan bukan penjahat. Ia mengetengahkan pendapatnya bahwa, penjahat adalah atavistis yakni secara genetik penjahat berasal dari salah satu jenis manusia sendiri, yaitu "home delinquens". Sehingga dengan demikian ia berpendapat bahwa manusia penjahat adalah bersifat degenerasi, dan tipe penjahat dapat diketahui dari ciri-ciri phsikis tertentu (Stigmata), seperti; mata yang cekung, dahi yang lebar, muka yang tidak simetris, ukuran tangan yang panjang, dan ciri lainnya yang khas. ${ }^{25}$ Dari ajaran Lombroso di atas, jelaslah bahwa ia sangat banyak dipengaruhi oleh aliran positivisme, dan dalam banyak ajaran tentang manusia penjahat ini digunakan metode pendekatan secara anthropo-biologi. ${ }^{26}$

Enrico Ferri (1856-1928) merupakan murid dari Lombroso yang berusaha menyebar luaskan ajaran Lombroso, tetapi ia mengakui pula pentingnya faktor-faktor lingkungan di samping faktor biologi dalam timbulnya kejahatan. ${ }^{27} \mathrm{Hal}$ ini secara tegas dinyatakan dalam bukunya yang berjudul "Sociologie Criminelle" yaitu, tiap-tiap kejahatan adalah resultante dari keadaan individu, psikis, dan sosial. Pada suatu waktu unsur yang satu lebih berpengaruh, kemudian yang lain tapi unsur individulah tetap yang paling penting. Keadaan sosial memberi bentuk pada kejahatan, tetapi ini berasal dari bakatnya yang anti-sosial. ${ }^{28}$

Pendapat dari mazhab lingkungan memandang beberapa faktor lingkungan sebagai kejahatan, seperti lingkungan yang memberi kesempatan akan timbulnya kejahatan; lingkungan pergaulan yang memberi contoh/ tauladan; lingkungan ekonomi (kemelaratan/ kemiskinan); dan lingkungan pergaualan yang berbeda-beda (Differential Association). ${ }^{29}$

Perkem-bangan mutakhir dari penyelidikan sebab akibat kejahatan diawali oleh hasil-

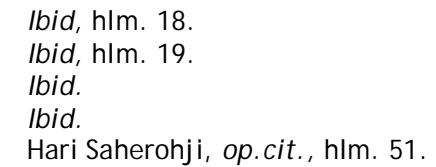

hasil penyelidikan yang gemilang yang telah dilakukan oleh William Healy dan Cyril Burt, hasil-hasil mana kemudian dapat menunjang teorinya yang dikenal dengan "multiple factors theory atau teori faktor jamak". Mempelajari kejahatan juga tentunya mempelajari pelaku dan kita tidak boleh melupakan peranan korban terhadap terjadinya kejahatan, namun yang terakhir ini tidak pernah mendapat perhatian bahkan ketika di minta kesaksiannya.

\section{Faktor-Faktor yang Dapat Menimbulkan Keja- hatan}

Sebab-musabab timbulnya kejahatan sangat kompleks dikarenakan banyak sekali faktor-faktor yang melatar belakanginya dimana faktor yang satu dengan faktor yang lainnya saling mempengaruhi. E.H Sutherland mengatakan bahwa, kejahatan adalah hasil dari faktor-faktor yang beraneka ragam dan bermacammacam dan faktor- faktor itu dewasa ini dan untuk selanjutnya tidak bisa disusun menurut suatu ketentuan yang berlaku umum tanpa ada pengecualian atau dengan perkataan lain untuk menerangkan kelakuan kriminil tidak ada teori ilmiah. ${ }^{30}$

Secara umum dapat diketahui bahwa faktor-faktor yang menimbulkan kejahatan dibagi dalam dua bagian. Pertama, faktor intern tentang sifat-sifat umum dari individu seperti: umur (dari sejak kecil hingga dewasa manusia mengalami perubahan jasmani dan rohani dan dalam tiap masa perubahan manusia dapat melakukan kejahatan); sex (hal ini berhubungan dengan keadaan psikis); kedudukan individu dalam masyarakat; pendidikan individu, hal ini mempengaruhi keadaan jiwa dan tingkah laku; masalah rekreasi/ hiburan individu; dan agama individu merupakan unsur pokok dalam kehidupan manusia yang merupakan kebutuhan spiritual. ${ }^{31}$

Tentang sifat-sifat khusus dari individu Maksudnya adalah keadaan kejiwaan dari individu. Peninjauan ini lebih dititk beratkan pada segi phisikologis. Pada masalah kepribadian

$30 \quad \mathrm{lbid}, \mathrm{hlm} .35$.

$31 \quad$ Ibid, hal. 36. 
sering timbul perilaku yang menyimpang, penyimpangan ini mungkin terhadap sistem sosial dan pola-pola kebudayaan. Perilaku yang menyimpang tersebut meliputi kelakuan yang menyimpang akibat mental desease atau rendahnya mental (bukan sakit jiwa); dan kelakuan yang menyimpang karena daya emosioniil. ${ }^{32}$

Kedua, faktor ekstern (faktor-faktor yang berada di luar individu). Faktor-faktor ekstern meliputi waktu kejahatan (untuk mengetahui pada saat mana kejahatan itu banyak dilakukan); tempat kejahatan (untuk mengetahui tempat-tempat seperti apa yang dijadikan tempat dilakukannya kejahatan); dan keadaan keluarga dalam hubungannya dengan kejahatan (merupakan satuan terkecil masyarakat yang di dalamnya terjadinya proses pembentukan kepribadian anak yang nantinya berpengaruh di masa ia dewasa.

Berikut adalah masalah-masalah keluarga yang dapat menjadi faktor pendorong ke arah kejahatan, yaitu; (a) Keluarga yang besar, di dalam kenyataan bahwa keluarga yang besar pada umumnya adalah keluarga yang kurang mampu berhubungan dengan keadaan tersebut maka tekanan ekonomi yang dirasakan juga berat dan perhatian kepada tiap-tiap anak menjadi berkurang karena jumlah anak yang harus diperhatikan sangat banyak; (b) Keluarga kecil, kaitannya dengan kejahatan apabila pada keluarga kecil terletak pada kedudukannya dalam keluarga antara anak sulung, bungsu, tunggal. Bagi anak tunggal yang biasanya dimanjakan maka apabila di dalam kehidupannya bermasyarakat akan mengalami kesulitan menyesuaikan diri, sehingga apabila ada permintaannya yang tidak dipenuhi maka ia bisa berbuat jahat; ${ }^{33}$ (c) Masalah perekonomian (faktor sosial ekonomi). Keadaan ekonomi sangat berpengaruh terhadap jiwa manusia, keadaan ekonomi merupakan faktor yang secara langsung maupun tidak langsung akan mempengaruhi pola-pola kehidupan masyarakat, contohnya orang miskin akan rendah diri, sehingga mencari jalan untuk memenuhi kebutuhannya dan salah satu jalannya

\footnotetext{
32 Ibid.

33 Ibid, hlm, 41-42
}

adalah timbulnya hasrat melakukan kejahatan. Begitupun dengan pengangguran yang membawa dampak negatif karena dapat meningkatkan tingkat terjadinya kejahatan terutama di kota besar yang merupakan tujuan urbanisasi. ${ }^{34}$

Berdasarkan penelitian (wawancara), diperoleh data primer sebagai berikut. Pertama, Pengurus LSM Lentera Perempuan WCC Banyumas mengemukanan faktor-faktor yang melatar belakangi kekerasan terhadap perempuan di Wilayah Hukum Polres Banyumas, yaitu: (a) Faktor ekonomi, biasanya faktor ini melatar belakangi terjadinya kekerasan dalam lingkup rumah tangga, misalnya: suami tidak memberikan nafkah, tidak memiliki mata pencaharian yang pasti, hal-hal tersebut yang memicu suami melakukan kekerasan terhadap perempuan khususnya adalah isterinya. Dalam faktor ekonomi juga termasuk kemiskinan juga menimbulkan kejahatan menurut Aristoteles dalam bukunya "Politiek" ; (b) Faktor budaya, masyarakat Indonesia menganut budaya patrilineal yang menempatkan perempuan sebagai makhluk yang harus tunduk kepada lelaki, akibatnya perempuan memiliki pola berpikir bahwa ia adalah makhluk yang lemah karena bergantung kepada kaum lelaki, sehingga perempuan tidak berani untuk membela hak-haknya; (c) Perselingkuhan, faktor ini juga melatar belakangi terjadinya kekerasan terhadap perempuan dalam lingkup rumah tangga hal ini dikarenakan pasangan memiliki pasangan selingkuh, misalkan pihak suami memilki simpanan perempuan lain atau pihak istri memiliki pria lain, sehingga memicu kecemburuan diantara pasangan yang dapat berujung terjadinya kekerasan. Dalam hal ini faktor lingkungan lebih banyak berpengaruh menurut E. Ferri di samping faktor biologis; dan (d) Kurangnya komunikasi antar keluarga, faktor ini paling sering melatar belakangi kekerasan terhadap anak perempuan, hal ini dikarenakan hubungan antara anak dengan orang tua tidak berjalan harmonis, sehingga sangat dimungkinkan apabila anak mengalami kekerasan yang biasanya dilakukan oleh kerabat dekat, orang tua tidak mengetahuinya, atau orang tua

\footnotetext{
$34 \quad$ Ibid, hlm. 45 dan 48.
} 
tidak dapat menempatkan diri sebagaimana mestinya, sehingga tidak jarang orang tua anak tersebutlah yang melakukan kekerasan.

Kedua, perempuan yang mengalami kekerasan atau korban kekerasan dapat diketahui faktor- faktor yang melatarbelakangi terjadinya kekerasan, yaitu faktor kesulitan ekonomi dan faktor perselingkuhan. Ketiga, dari Kepolisian Polres Banyumas dapat diketahui bahwa faktorfaktor yang melatar belakangi kekerasan terhadap perempuan di Wilayah Hukum Polres Banyumas, yaitu: faktor ekonomi, berupa rendahnya pemasukan, dikarenakan pasangan suami istri tidak memiliki pekerjaan yang tetap, atau karena suami yang tidak dapat menafkahi istri, sehingga memicu pertengkaran yang berujung pada terjadi kekerasan; dan perselingkuhan yang memicu kecemburuan salah satu pasangan, sehingga dapat berujung pada terjadinya kekerasan.

Sudarto berpendapat bahwa perbuatan jahat sebagai gejala masyarakat di pandang secara konkrit sebagaimana terwujud dalam masyarakat (sociaal verschijnsel, erscheinung, poena), ialah perbuatan manusia yang memperkosa/menyalahi norma-norma dasar dari masyarakat dalam konkreto ini adalah pengertian "perbuatan jahat" dalam arti krimonologis (criminologisch misdaadsbegrip). ${ }^{35}$ Definisi kejahatan dapat dipandang secara sosiologis memiliki dua unsur/elemen, yaitu kejahatan itu adalah yang merugikan secara ekonomis; dan merugikan secara psychologis/ dan melukai perasaan susila dari suatu kelompok manusia di mana orang-orang itu oleh karenanya berhak melahirkan celaan.

Pengertian secara sosiologis ini lebih luas dari pada pengertian secara yuridis, sebab tidak hanya menekankan pada pelanggaran hukum, melainkan juga segi-segi di luar hukum, misalnya: suatu perbuatan yang tidak melanggar hukum tetapi sudah patut mendapat celaan dari masyarakat (buang air kecil disembarang tempat). ${ }^{36}$ Apabila dikaitkan dengan data primer yang diperoleh maka kasus-kasus keke-

\footnotetext{
35 Sudarto, Op.cit, hlm. 23.
}

36 Ibid, hlm. 15 rasan terhadap perempuan merupakan kej ahatan yang berupa reaksi anti sosial, yang dapat membawa kerugian bagi perempuan berupa kesengsaraan baik fisik maupun psikis dan dari kasus-kasus tersebut termasuk kekerasan rasional.

Kekerasan terhadap perempuan termasuk kedalam kejahatan rasional menurut Martin $\mathrm{R}$. Haskell dan Lewis Yablonsky, dikatakan sebagai kejahatan rasional karena kejahatan kekerasan terhadap perempuan merupakan kejahatan yang tidak legal akan tetapi tidak ada sanksi sosialnya, melainkan sanksi pidana berdasarkan peraturan perundang- undangan yang berlaku. Mengenai faktor-faktor terjadinya kejahatan dalam hal ini adalah kekerasan terdapat berbagai pendapat dikalangan kriminolog.

Lombroso berpendapat bahwa manusia penjahat adalah bersifat degenerasi, dan tipe penjahat dapat diketahui dari ciri- ciri psikis tertentu (stigmata), seperti; mata yang cekung, dahi yang lebar, muka yang tidak simetris, ukuran tangan yang panjang, dan ciri lainnya yang khas. $^{37}$ E. Ferri berpendapat bahwa, tiap-tiap kejahatan adalah resultante dari keadaan individu, physikis dan sosial. Pada suatu waktu unsur yang satu lebih berpengaruh, kemudian yang lain tapi unsur individulah tetap yang paling penting. Keadaan sosial memberi bentuk pada kejahatan, tetapi ini berasal dari bakatnya yang anti-sosial. ${ }^{38}$

Faktor sosial yang dimaksud tidak terlepas dari lingkungan yang ada di sekitar individu tersebut, sedangkan faktor individu yang dimaksud adalah faktor intern. Faktor-faktor intern meliputi sifat-sifat umum dari individu seperti umur (dari sejak kecil hingga dewasa manusia mengalami perubahan jasmani dan rohani dan dalam tiap masa perubahan manusia dapat melakukan kejahatan); sex (hal ini berhubungan dengan keadaan psikis); kedudukan individu dalam masyarakat; pendidikan individu, hal ini mempengaruhi keadaan jiwa dan tingkah laku; dan masalah rekreasi/hiburan individu; agama individu merupakan unsur pokok

\footnotetext{
37 Ibid., hlm. 18.
}

38 lbid. 
dalam kehidupan manusia yang merupakan kebutuhan spiritual. ${ }^{39}$ Tentang sifat-sifat khusus dari individu seperti kelakuan yang menyimpang akibat mental desease atau rendahnya mental (bukan sakit jiwa); dan kelakuan yang menyimpang karena daya emosioniil. ${ }^{40}$

Selain faktor intern yang merupakan faktor yang mendorong orang melakukan kejahatan dalam hal ini adalah kekerasan adalah faktor ekstern, yaitu waktu kejahatan (untuk mengetahui pada saat mana kejahatan itu banyak dilakukan); tempat kejahatan, untuk mengetahui tempat-tempat seperti apa yang dijadikan tempat dilakukannya kejahatan; keadaan keluarga dalam hubungannya dengan kejahatan (merupakan satuan terkecil masyarakat yang di dalamnya terjadinya proses pembentukan kepribadian anak yang nantinya berpengaruh di masa ia dewasa); dan masalah perekonomian/faktor sosial ekonomi (keadaan ekonomi sangat berpengaruh terhadap jiwa manusia, keadaan ekonomi merupakan faktor yang secara langsung maupun tidak langsung akan mempengaruhi pola-pola kehidupan masyarakat, contohnya orang miskin akan rendah diri, sehingga mencari jalan untuk memenuhi kebutuhannya dan salah satu jalannya adalah timbulnya hasrat melakukan kejahatan. Begitupun dengan pengangguran yang membawa dampak negatif karena dapat meningkatkan tingkat terjadinya kejahatan terutama di kota besar yang merupakan tujuan urbanisasi). ${ }^{41}$

Berdasarkan teori-teori tersebut dan dikaitkan dengan data primer yang diperoleh maka dapat diketahui bahwa faktor yang menyebabkan seseorang melakukan kekerasan terhadap perempuan merupakan faktor jamak atau mutiple factors theory. Ada tiga hal yang dapat dikategorikan sebagai mutiple factors theory. Pertama, faktor intern, yang meliputi sifat-sifat umum dari individu seperti umur (pelaku tindak pidana kekerasan terhadap perempuan rata-rata merupakan usia produktif yaitu antara 30- 50 tahun); sex (pelaku dari tindak pidana

\footnotetext{
39 Ibid., hlm. 36.

40 Ibid.

41 lbid, hlm. 45. \&48.
}

kekerasan terhadap perempuan adalah berjenis kelamin laki-laki); kedudukan individu dalam masyarakat (rata-rata pelaku kekerasan terhadap perempuan memiliki kedudukan biasa dalam masyarakat, tetapi juga ada yang pejabat); pendidikan individu (pelaku rata-rata berpendidikan di bawah Strata satu (S1)); masalah rekreasi/hiburan individu (pelaku rata-rata berasal dari kalangan ekonomi sulit, sehingga jarang mendapatkan kesempatan untuk berekreasi karena keterbatasan biaya); dan agama (hampir seluruh pelaku tindak pidana kekerasan terhadap perempuan tidak patuh dalam menjalankan aturan agamanya, sebab apabila ia patuh terhadap agamanya maka tidak mungkin ia melakukan kekerasan apalagi terhadap istrinya sendiri).

Seringkali persoalan dan sangat remeh dapat menimbulkan tindak kekerasan yang melampaui batas dan sama sekali tidak terukur. Pembunuhan dan penyiksaan sadis yang dialami korban hanya karena persoalan salah ucap dan kurangnya pelayanan seperti sering kita dengar dari laporan media adalah bukti dari ketidakseimbangan antara tingkat penyebab dan akibat. ${ }^{42}$

Tentang sifat-sifat khusus dari individu, maka berdasarkan pada data primer yang berupa hasil wawancara, maka mengenai faktor sifat-sifat khusus dari individu yang paling banyak adalah faktor kelakukan yang menyimpang karena daya emosionil. Terjadinya kekerasan terhadap perempuan sebagian besar terjadi dalam lingkup rumah tangga yang dipicu pertengkaran, sehingga pada saat emosi memuncak maka terjadilah kekerasan terhadap perempuan.

Kedua, faktor ekstern yang meliputi waktu kejahatan (biasanya kekerasan terhadap perempuan terjadi mulai pertengkaran dan memuncak dengan terjadinya kekerasan); tempat kejahatan (biasanya dilakukan di rumah atau di hotel apabila korban kejahatan adalah pasangan selingkuh dari pelaku); keadaan keluarga (biasanya kekerasan terhadap perempuan terjadi pada keluarga besar yang memiliki anak

42 Ibid. hlm. 121. 
dalam jumlah yang banyak, sehingga mengalami kesulitan ekonomi yang merupakan pemicu dominan terjadinya kekerasan terhadap perempuan); masalah perekonomian (seperti yang telah dikatakan bahwa faktor ekonomi merupakan faktor yang paling dominan dalam terjadinya tindak pidana kekerasan terhadap perempuan dalam lingkup rumah tangga, hal ini dikarenakan apabila pihak suami tidak dapat menafkahi kehidupan rumah tangga, maka akan memicu pertengkaran yang menyebabkan terjadinya kekerasan). Jadi menurut pendapat Aristoteles dalam hal ini faktor kemiskinan menjadi faktor terjadinya kekuasaan.

Ketiga, faktor lingkungan dalam hal ini adalah faktor budaya yang dianut sistem patrilineal. Sistem patrilineal merupakan sistem budaya yang menempatkan kaum lelaki sebagai kepala rumah tangga, makhluk yang dominan dari pada perempuan, sehingga sangat dimungkinkan kaum lelaki merasa dirinya lebih kuat, lebih pandai jadi memandang kaum perempuan sebagai kaum yang lemah, sehingga dapat diperlakukan seenaknya.

Ironisnya, negara ini mempunyai tugas memberikan perlindungan dan jaminan bagi seluruh masyarakat sering kali menerapkan standar gender dalam menyikapi masalah perempuan. Hal tersebut tercermin dalam kebijakankebijakan negara secara implicit maupun eksplisit melestarikan peran gender perempuan. Beberapa kebijakan pemerintah melalui produk hukum juga membakukan peran gender perempuan misalnya dalam Undang-Undang Nomor 1 Tahun 1974 Tentang Perkawainan, di sini disebutkan perempuan sebagai ibu rumah tangga dan suami sebagai kepala rumah tangga. J adi, faktor-faktor penyebab seorang melakukan kekerasan terhadap perempuan yaitu karena faktor individu dari faktor intern dan ekstern, yang apabila dilihat secara teori disini terdapat faktor jamak atau multiple factor.

\section{Penutup \\ Simpulan}

Berdasarkan pembahasan di atas, maka dapat disimpulkan beberapa hal berikut ini.
Pertama, bentuk-bentuk tindak pidana kekerasan terhadap perempuan yang terjadi di wilayah hukum Polres Banyumas, yaitu: (a) Kekerasan Dalam Rumah Tangga (KDRT); (b) Kekerasan Terhadap Anak (KTA); (c) Kekerasan seksual misalnya pemerkosaan dan pencabulan; (d) Kekerasan Dalam Pacaran (KDP); (e) Anak Bermasalah Dengan Hukum (ABH); dan (f) Buruh Migran. Bentuk kekerasan yang paling sering terjadi adalah KDRT yang berupa kekerasan fisik, penelantaran rumah tangga, psikis, dan kekerasan seksual sekitar 40\% Seksual 30, KTA 14\% Buruh Migran 9\% KDP 7\%

Kedua, faktor-faktor yang melatar belakangi terjadinya tindak pidana kekerasan terhadap perempuan di wilayah hukum Polres Banyumas, meliputi: (a) faktor ekonomi; (b) faktor kebudayaan patrilineal, c. faktor perselingkuhan, d. faktor kurangnya komunikasi dalam keluarga. Faktor ekonomi adalah faktor yang paling dominan yaitu sebesar $70 \%$ 15\% faktor budaya, $10 \%$ fakor perselingkuhan, dan $5 \%$ faktor kurangnya komunikasi.

Ketiga, perempuan yang mengalami kekerasan tidak berani melaporkan kekerasan tersebut ke pihak yang berwajib atau ke proses hukum. Hal ini dikarenakan korban biasanya memiliki hubungan yang dekat dengan pelaku, apabila korbannya adalah istri, maka alasannya istri masih mencintai suaminya (pelaku) atau karena alasan malu aibnya diketahui banyak orang apabila kekerasan tersebut dilaporkan.

\section{Saran}

Bagi perempuan-perempuan Indonesia, agar lebih bersikap berani dan tegas dalam menghadapi kekerasan yang menimpa dirinya, misalkan dengan melaporkan pelaku kepada aparat penegak hukum khususnya kepolisian agar kasusnya dapat diproses secara hukum. Hal ini supaya mengetahui hak-haknya perempuan sebagai warga negara yang dijamin dan dilindungi oleh hukum. dan agar pelaku menjadi jera. 


\section{Daftar Pustaka}

Ahmadi, Wiratni. "Hak dan Kewajiban Wanita dalam Keluarga Menurut UU No. 1 Tahun 1974 tentang Perkawinan". J urnal Hukum Pro J usititia, Vol. 26 No. 4 Oktober 2008;

Angkasa. "Over Capacity Narapidana Pemasyarakatan di Lembaga Pemasyarakatan, Faktor Penyebab, Implikasi Negatif, serta Solusi dalam Upaya Optimalisasi Pembinaan Narapidana". J urnal Dinamika Hukum, 2010. Fakultas Hukum Unsoed, Purwokerto;

Atmasasmita, Romli. 1983. Capita Selecta Kriminologi. Bandung: Armico;

Fahmi. "Penegakan Hukum Tindak Pidana Trafficking in Person di Kabupaten Karimun, Kepulauan Riau". Jurnal Hukum Respublica, Vol. 7 No. 1 Tahun 2007;

Gulton, Maidin dan Taufik Siregar. "Penegakan Hukum Atas Tindak Pidana Perdagangan (Trafficking) Anak". Jurnal Hukum Pro J ustitla, Tahun XXIII No. 2 April 2005;

Hibnu Nugroho, "Perlindungan Hukum Bagi Korban "Bank Gelap", J urnal Dinamika Hukum Vol. 9 2009. Fakultas Hukum Unsoed, Purwokerto,

Kusuma, Mulyana W. 1981. Analisa Kriminologi tentang Kejahatan-Kejahatan Kekerasan. J akarta: Ghalia Indo-nesia;

Manan, Mohammad Azzam. "Kekerasan dalam Rumah Tangga dalam Perspektif Sosiologis". J urnal Legislasi Indonesia, Dirjen Kum Dan Rl, J akarta, Vol. 5, 2008;

Muflichah, Siti dan Rahadi Wasi Bintoro. "Traffiking: Suatu Studi Tentang Perdagangan Perempuan dari Aspek Sosial, Budaya dan Ekonomi di Wilayah Kab. Banyumas". Jurnal Dinamika Hukum, 2009. Fakultas Hukum Unsoed, Purwokerto;

Raharjo, Agus. "Mediasi sebagai Basis dalam
Penyelesaian Perkara Pidana". J urnal Mimbar Hukum, Fakultas Hukum UGM, Yogyakarta, Volume 20, 2008;

Sunaryo dan Nurul Hidayat. "Pendayagunaan Teknologi, Informasi dalam Pemberdayaan Masyarakat untuk Mengawasi Bekerjanya Sistem Peradilan PIdana di J awa Tengah". Jurnal Dinamika Hukum, Vol. 10 No. 3 September 2010. Fakultas Hukum Unsoed, Purwokerto;

Retnaningrum, Dwi Habsari. "Incest Sebagai Bentuk Manifestasi Kekerasan Terhadap Perempuan". Jurnal Dinamika Hukum, Vol. 9, 2009. Fakultas Hukum UNSOED, Purwokerto;

Saherodji, Hari. 1980. Pokok-Pokok Kriminologi. J akarta: Aksara Baru;

Samosir, C. Djisman. "Faktor-Faktor Yang Mengakibatkan Tidak Terungkapnya Suatu Kejahatan". J urnal Hukum Pro J usititia, Vol. 24 No. 3 J uli 2006;

Subekti, Trusto, "Sahnya Perkawinan Menurut UU No. 1/ 1974 Tentang Perkawinan Ditinjau dari Hukum Perjanjian". J urnal Dinamika Hukum FH Unsoed, Vol. 10 No. 3 September 2010;

Sudarto. 1990. Hukum Pidana Jilid 1 A-B. Purwokerto: Fak. Hukum UNSOED;

Wahid, Abdul \& Muhammad Irfan, 2009, Perlindungan Terhadap Korban Kekerasan Seksual (Advokasi Atas Hak Asasi Perempuan), Bandung: Refika Aditama;

Widyaastuti, A. Reni. "Hukum dan Kekerasan dalam Rumah Tangga". Jurnal Hukum Pro J usitita, Vol. 25 No. 3 J uli 2007;

Yulia, Rena. “Implementasi UU No. 23 Tahun 2004 tentang Penghapusan KDRT dalam Proses Penegakan". Jurnal Hukum Pro J usitita, Vol. 24 No. 3 J uli 2006. 